\title{
Effect of pretreatment on bioactive compounds in wild rocket juice
}

\author{
Elżbieta Radziejewska-Kubzdela $^{1}$ (D) Anna Olejnik $^{2} \cdot$ Róża Biegańska-Marecik $^{1}$
}

Revised: 3 July 2019/Accepted: 30 July 2019/Published online: 6 August 2019

(C) The Author(s) 2019

\begin{abstract}
The aim of the study was to determine the effect of pretreatment with hot water or steaming on glucosinolates, polyphenols contents and antioxidant capacity in obtained raw juices. Moreover, in vitro cytotoxic activity of the raw juice to the cells derived from the gastrointestinal tract, including the small intestine (IEC-6 cell line), colon (Caco-2 cell line) and the liver (HepG2 cell line) were also investigated. The dominant glucosinolates in the wild rocket leaves were glucoraphanin $(36 \%)$ and dimeric 4-mercaptobutyl (30\%), followed by glucosativin and glucoerucin, $11 \%$ per each. Glucothiobeinin $(6 \%)$, glucobrassicin (1\%), 4-methoxyglucobrassicin (1\%) and two unidentified compounds $(4 \%)$ were also detected in rocket leaves. In terms of phenolic compounds, quercetin constituted the majority $(55 \%)$ and the rest composed of hydroxycinnamic acids. In raw juices produced from steamed, pretreatment with hot water and untreated (control) leaves, glucosinolate contents were lower about $21 \%$, $37 \%$ and $53 \%$, respectively, than their levels in the raw material. The highest content of polyphenols among the juices tested $(45.4 \mathrm{mg} / 100 \mathrm{~g}$ fresh weight) and antioxidant capacity $(5.8 \mu \mathrm{mol}$ Trolox $/ 1$ g f.w.) was recorded in the raw juice from pretreated leaves with hot water. The wild rocket raw juice concentrations responsible for a $50 \%$ reduction in Caco-2 and HepG2 cell viability were
\end{abstract}

Elżbieta Radziejewska-Kubzdela

elarad@up.poznan.pl

1 Institute of Technology of Food of Plant Origin, Poznań University of Life Sciences, Wojska Polskiego 31, 60-624 Poznań, Poland

2 Department of Biotechnology and Food Microbiology, Poznań University of Life Sciences, Wojska Polskiego 48, 60-627 Poznań, Poland estimated at $1.87 \pm 0.08 \mathrm{mg} / \mathrm{mL}$ and $3.54 \pm 0.29 \mathrm{mg} / \mathrm{mL}$. The viability of the IEC- 6 cells was reduced by only $19.04 \%$, at the maximum concentration $(3.6 \mathrm{mg} / \mathrm{mL})$ of the raw juice.

Keywords Wild rocket · Polyphenols · Glucosinolates · Antioxidant capacity

\section{Introduction}

Wild rocket (Diplotaxis tenuifolia (L.) DC.) belongs to the family Brassicaceae. Rocket leaves contain many bioactive compounds, such as polyphenols, especially flavonoids. They protect the colonic epithelium from oxidative damage and contribute to lowering the risk of cardiovascular diseases (Chun et al. 2017). The pungent taste of leaves is linked with the presence of glucosinolates (GLS). The dominant compound is dimeric 4-mercaptobutyl GLS (glucosativin), probably derived from the S-demethylation of 4-methylthiobutyl GLS (glucoerucin) (Bennett et al. 2006). GLS are located in plant vacuoles. A disruption of tissue continuity (e.g. comminution) facilitates their hydrolysis by myrosinase enzyme present in the cytosol or myrosin cells (Radziejewska-Kubzdela and Olejnik 2016). Breakdown products of these compounds have potentially beneficial health effects associated with their anti-cancer activity. Numerous studies indicate a correlation between the potential to lower the risk of certain cancers (e.g. breast, cervical, prostate, lung, stomach or colon) and increased consumption of Brassicaceae vegetables, constituting their good sources (van Poppel et al. 1999; London et al. 2000; Giovannucci et al. 2003; Sapone et al. 2007). Degradation products of GLS can inhibit carcinogenesis and different development stages of the illness. 
Rocket is consumed in many countries in the minimally processed form. An interesting alternative seems to be connected with the use of this raw material to produce juice, which may be a part of vegetable or fruit juices. The juice yield may be increased by heat pretreatment of leaves, as indicated by such an effect observed in the case of carrot or red beetroot mash (Zadernowski and Oszmiański 1994; Mannozzi et al. 2018). The increase of yield often leads to improve juice quality with regard to the content of bioactive compounds. In the literature there is no data on either the content or profile of phenolic compounds, GLS in wild rocket juice, which is used in green vegetable juices.

The aim of the study was to determine the effect of pretreatment with hot water or steaming of leaves on the contents of phenolic compounds and GLS as well as antioxidant capacity in the produced raw juices. The tested parameters were determined in the raw material, in the mashes obtained after the comminution of the pretreated leaves and in raw juices. Currently used plants in new forms may induce cytotoxic effects on both normal and cancer cells, especially on cells of the digestive system. Therefore, the cytotoxicity of wild-rocket juice to small intestine cells (IEC-6 cell line), hepatocellular carcinoma cells (HepG 2 cell line) and colon cancer cells (Caco- 2 cell line) was investigated in this work.

\section{Materials and methods}

\section{Raw material}

Wild rocket leaves (Diplotaxis tenuifolia (L.) DC.) were purchased from a horticultural farm located near Poznań, Poland. Leaves with defects were removed manually.

\section{Chemicals}

HPLC gradient grade acetonitrile, $\geq 99.9 \%\left(\mathrm{CH}_{3} \mathrm{CN}\right)$ and methanol $(\mathrm{MeOH})$ were purchased from Sigma Aldrich ChemieGmbH (Steinheim, Germany). 2,2-azinobis-(3ethylbenzothiazoline-6-sulphonic acid) (ABTS), 6-hydroxy-2,5,7,8-tetramethylchroman-2-carboxylic acid (Trolox), HPLC grade acetic acid $\left(\mathrm{CH}_{2} \mathrm{O}_{2}\right)$, DEAE Sephadex A-25, purified sulphatase from Helix pomatia and standards for phenolic compounds were supplied from Sigma Aldrich Chemie Co. (St. Louis, USA). Chlorogenic acid was obtained from Sigma Aldrich Chemie Co. (Buchs, Switzerland). Monobasicpotassium phosphate $\left(\mathrm{KH}_{2} \mathrm{PO}_{4}\right)$ was provided by Sigma AldrichChemie Co. (Tokyo, Japonia), while sodium acetate $\left(\mathrm{C}_{2} \mathrm{H}_{3} \mathrm{NaO}_{2}\right)$ was obtained from Chempur (Piekary Śląskie, Poland), glucotropaeolin from Roth (Karlsruhe, Germany), imidazole $\left(\mathrm{C}_{3} \mathrm{H}_{4} \mathrm{~N}_{2}\right)$ from Merck Schuchardt OHG (Hohenbrunn, Germany). Ultra pure water was produced in the laboratory using a Direct-Q UV3Water Purification System (Millipore, Billerica, USA).

\section{Technological process}

Wild rocket leaves were washed and cut into pieces of $3 \mathrm{~cm}$ in length by hand, then divided into three batches. One bath was put aside without any pretreatment (control). One batch (leaf: water ratio as 90:10, w/w\%) was put in hot water $\left(90^{\circ} \mathrm{C}\right)$ for $5 \mathrm{~min}$. The last third batch was steamed for $10 \mathrm{~min}$ in a Thermomix TM6 (Wuppertal, Vorwerk, Germany). Then, leaves from all batches were comminuted in a Thermomix TM6 for $1 \mathrm{~min}$ and each batch was divided into two parts. One part was cooled in tap water, then was frozen in liquid $\mathrm{N}_{2}$ and stored at $-50{ }^{\circ} \mathrm{C}$ for further analysis. The other part was pressed in a Para-press laboratory press (Arauner Kitzingen, Kitzingein, Germany) at $0.28 \mathrm{MPa}$ for $10 \mathrm{~min}$. The obtained raw juices were frozen in liquid $\mathrm{N}_{2}$ and stored at $-50{ }^{\circ} \mathrm{C}$.

\section{Juice yield}

The yield of wild rocket juice (Y) was calculated according to the following equation:

Yield $(\%)=\frac{\text { Amount of juice recovered }}{\text { Amount of mash taken }} \times 100$

(Turk et al. 2010)

\section{Glucosinolate analysis}

All samples were analyzed according to ISO 9167-1 method (ISO9167-1 1992). The analysed samples were freeze-dried (raw material, mashes and raw juices). Next samples $(0.5 \mathrm{~g})$ were extracted twice with $3 \mathrm{~mL}$ boiling methanol solution $(700 \mathrm{~g} / \mathrm{L})$ in a water bath at $75^{\circ} \mathrm{C}$ for 20 min. Obtained extracts were purified in an ion exchange mini-column (DEAE Sephadex A-25). The column was washed once with $2 \mathrm{~mL}$ imidazol formate $(6 \mathrm{~mol} / \mathrm{L})$ and twice with $1 \mathrm{~mL}$ Millipore water and then loaded with $6 \mathrm{~mL}$ of each extract. Purified sulphatase from $H$. pomatia was added to the column and incubated overnight at room temperature. A known amount of glucotropaeolin was added to each sample during extraction as the internal standard. Desulphoglucosinolates were eluted with water and were separated using the Agilent Technologies 1200 Rapid Resolution LS system (Waldbronn, Germany) equipped with a Poroshell 120, SB-C18 column $(4.6 \times 150 \mathrm{~mm}, 2.7 \mu \mathrm{m})$ (Wilmington, USA) at a flow rate of $1 \mathrm{~mL} / \mathrm{min}$ at $30^{\circ} \mathrm{C}$. The used mobile phase was ultra pure water $(\mathrm{A})$, acetonitrile-ultra pure water mixture (20:80 
$\mathrm{v} / \mathrm{v}, \mathrm{B})$. During $30 \mathrm{~min}$ of total run time; the gradient flow was as follows: $100 \% \mathrm{~A} / 0 \% \mathrm{~B}$ for $1 \mathrm{~min}$, then within $22 \mathrm{~min}-100 \% \mathrm{~B}$ and within $5 \mathrm{~min}-100 \% \mathrm{~B}$, after which the column was equilibrated at $100 \%$ A for 2 min. A UV detector was used at a wavelength of $229 \mathrm{~nm}$. Desulphoglucosinolates were quantified with respect to glucotropaeolin and the response factor (ISO9167-1 1992).

\section{Determination of phenolic compounds}

$10 \mathrm{~g}$ of all samples were weighed and homogenised with $50 \mathrm{~mL}$ of $700 \mathrm{~g} / \mathrm{L}$ methanol using an IKA T-25 homogeniser (Staufen, Germany). Homogenates were shaken for 15 min in a Water Bath Shaker type 357 (Elpin, Lubawa, Poland) and then centrifuged in a MPW-351R centrifuge (Warszawa, Poland) at $3000 \times g$ for $20 \mathrm{~min}$. Each extraction procedure was performed twice and obtained phenolic extracts were combined then evaporated in a vacuum Büchi R-205 evaporator (Flawil, Switzerland) at $40{ }^{\circ} \mathrm{C}$. Concentrated extracts were diluted up to $25 \mathrm{~mL}$ with ultra pure water (Vallejo et al. 2002).

Phenolic compounds were determined by the LC Agilent Technologies 1200 Rapid Resolution system equipped with a Poroshell 120, SB-C18 column $(4.6 \times 150 \mathrm{~mm}$, $2.7 \mu \mathrm{m})$. The mobile phase consisted of $60 \mathrm{~g} / \mathrm{L}$ acetic acid in $0.002 \mathrm{~mol} / \mathrm{L}$ sodium acetate (solvent $\mathrm{A}$ ) and acetonitrile (solvent B) (Tsao and Yang 2003). The flow rate was $1 \mathrm{~mL} / \mathrm{min}$ and the total run time was $35 \mathrm{~min}$. The system was operated with a gradient flow program: 0-15\% B for $15 \mathrm{~min}, 15-30 \% \mathrm{~B}$ for $25 \mathrm{~min}, 30-50 \% \mathrm{~B}$ for $5 \mathrm{~min}$ and $50-100 \%$ B for $5 \mathrm{~min}$. Two phenolic groups (hydroxycinnamic acid derivatives at $320 \mathrm{~nm}$ as chlorogenic acid equivalents and flavonols at $360 \mathrm{~nm}$ as quercetin equivalents) were determined. Total phenolic compounds was calculated as the sum of hydroxycinnamic acid derivatives and flavonols (Tsao and Yang 2003).

\section{Antioxidant capacity by $\mathrm{ABTS}^{+}$: free radical scavenging assay}

2.2-Azino-bis-(3-ethylbenzothiazoline-6-sulphonic acid) radical monocation scavenging activity was determined according to a procedure described by Re et al. (1999). $\mathrm{ABTS}^{+}$was obtained by reacting $0.007 \mathrm{~mol} / \mathrm{L}$ ABTS water solution with $0.00245 \mathrm{~mol} / \mathrm{L}$ potassium persulphate. The phenolic extract $(50 \mu \mathrm{L})$ was mixed with $5 \mathrm{~mL}$ diluted ABTS $^{+}$solution and its absorption was measured at $734 \mathrm{~nm}$ after $6 \mathrm{~min}$ at $30{ }^{\circ} \mathrm{C}$. The percentage inhibition of $\mathrm{ABTS}^{+}$by the phenolic extract was calculated according to the formula:

$\%$ Inhibition $=\left[\frac{A c_{(0)}-A a_{(t)}}{A c_{(0)}}\right] \times 100$ were $A c_{(0)}$ is the absorbance $\mathrm{ABTS}^{+}$without sample (control) at $t=0 \mathrm{~min}, A a_{(\mathrm{t})}$ is the absorbance of the phenolic extract at $t=6 \mathrm{~min}$. The antioxidant capacity of tested samples, calculated as percentage inhibition of ABTS $^{+}$, was equated against a Trolox standard curve (1.5-15 $\mu \mathrm{mol} / \mathrm{L})$ (Katalinic et al. 2005). 6-hydroxy-2,5,7,8tetramethylchroman-2-carboxylic acid (Trolox) was used as a standard and the antioxidant capacity was expressed as micromoles of Trolox per $1 \mathrm{~g}$ f.w. (fresh weight).

\section{Cytotoxic activity of wild rocket raw juice}

The Caco-2 (ECACC 86010202), HepG2 (ECACC 85011430) and IEC-6 (ECACC 88071401) cell lines were obtained from the European Collection of Cell Cultures (ECACC) with Sigma-Aldrich (St. Louis, USA) supply. Cells were cultured in Dulbecco's Modified Eagle's Medium (DMEM; Sigma-Aldrich), supplemented with $10 \%$ heat-inactivated fetal bovine serum (FBS; Gibco, Grand Island, NY, USA), $1 \%$ non-essential amino acids 100X (Sigma-Aldrich) and $50 \mathrm{mg} / \mathrm{L}$ gentamycin (Gibco, Grand Island, NY, USA). The medium used in the IEC-6 cell culture was also supplemented with $1 \mu \mathrm{M}$ insulin (Sigma-Aldrich). The cells were maintained at $37{ }^{\circ} \mathrm{C}$ in a humidified atmosphere $\left(5 \% \quad \mathrm{CO}_{2}, 95 \%\right.$ air $)$. The cells were cultured according to the recommendations of ECACC.

The cells were grown in 96-well plates at an initial density of $2.5 \times 10^{4}$ cells $/ \mathrm{cm}^{2}$. The 24 -hour cultures were treated with wild rocket raw juice at concentrations ranging from 0.03 to $3.60 \mathrm{mg} / \mathrm{mL}$ and incubated for $48 \mathrm{~h}$ under standard culture conditions.

The cytotoxic effect of the raw juice on the viability of Caco-2 and IEC-6 and HepG2 cells was evaluated using an assay based on the cleavage of the yellow dye MTT (3(4,5-dimethylthiazol-2-yl)-2,5-diphenyltetrazolium bromide; Sigma-Aldrich) to purple formazan crystals by mitochondrial dehydrogenase enzymes, which are active only in living cells (Mosmann 1983). After treatment of the cells with wild rocket raw juice, the MTT solution was added at a concentration $0.5 \mathrm{mg} / \mathrm{mL}$. The cell cultures were incubated at $37{ }^{\circ} \mathrm{C}$ for $3 \mathrm{~h}$ and then formazan crystals were extracted with acidic isopropanol for $20 \mathrm{~min}$ at room temperature. Absorbance was determined at two different wavelengths $(570 \mathrm{~nm}$ and $690 \mathrm{~nm}$-reference) using a Tecan M200 Infinite microplate reader (Tecan Group Ltd., Männedorf, Switzerland).

Based on the obtained results, dose-response curves were plotted and cytotoxic doses were calculated using the following equations: 
$\mathrm{Y}=\mathrm{Y}_{\min }+\left(\mathrm{Y}_{\max }-\mathrm{Y}_{\min }\right) /\left(1+10^{\left(\left(\operatorname{LogEC}_{50}-\log \mathrm{X}\right) \times \mathrm{s}\right)}\right)$,

$\operatorname{LogEC}_{10}=\operatorname{LogEC}_{50}-(1 / \mathrm{s}) \times \log (10 /(100-10))$,

$\mathrm{EC}_{10}=10^{\mathrm{LogEC}_{10}}$

where $Y_{\min }$ and $Y_{\max }$ are the estimated value of the minimal and maximal response, respectively; $\mathrm{X}$ is the wild rocket juice concentration; $\mathrm{EC}_{50}$ and $\mathrm{EC}_{10}$ are the concentrations, at which wild rocket juice reduces cell proliferation and viability by $50 \%$ and $10 \%$, respectively; $\mathrm{s}$ is the slope of the curve.

\section{Statistical analysis}

The analyses were carried out in triplicate. The analysis of variance (ANOVA) was conducted to determine the significance of the main effects. Differences between the mean values of multiple groups were analysed by parametric Tukey's post hoc test. Statistical significance was considered at $P<0.05$. The STATISTICA version 13.1 software (Statsoft, Inc., Tulsa, OK, USA) was used.

\section{Results and discussion}

\section{Juice yield}

Steaming of comminuted leaves resulted in an increase $25 \%$ in the raw juice yield when compared to juice yield of untreated leaves (control) (44\%). This ratio was $17 \%$ in hot water treated samples.

\section{Glucosinolates profile}

The total glucosinolate concentration of raw material was $210 \mathrm{mg} / 100 \mathrm{~g}$ f.w. (Table 1). The recorded glucosinolate content in literature for Diplotaxis ranges from $37.4 \mathrm{mg} /$ $100 \mathrm{~g}$ f.w. to $229 \mathrm{mg} / 100 \mathrm{~g}$ f.w. [calculated on the basis of the dry matter content $(8.5 \%)$ determined in the tested rocket leaves (data not published)] (Bell et al. 2015; Pasini et al. 2012; Taranto et al. 2016). The percentage contribution of individual glucosinolates to total content was $36 \%$ of glucoraphanin, $30 \%$ of dimeric 4-mercaptobutyl (DMB-GLS,) $11 \%$ of glucosativin, $11 \%$ of glucoerucin, $6 \%$ of glucothiobeinin, $1 \%$ of glucobrassicin and $1 \%$ of 4-methoxyglucobrassicin each and $4 \%$ of two unidentified compounds (calculated on the basis of values in Table 1). Pasini et al. (2012) in their studies on 37 rocket accessions indicated glucoraphanin (17.6-63\%), DMB-GLS $(12-49.5 \%)$ and glucoerucin $(7.7-28.1 \%$, ) as dominant compounds. They also detected of glucothiobeinin, 4-OHglucobrassicin and glucobrassicin. Additionally, they identified glucoalyssin, glucosinalbin, progroitrin and

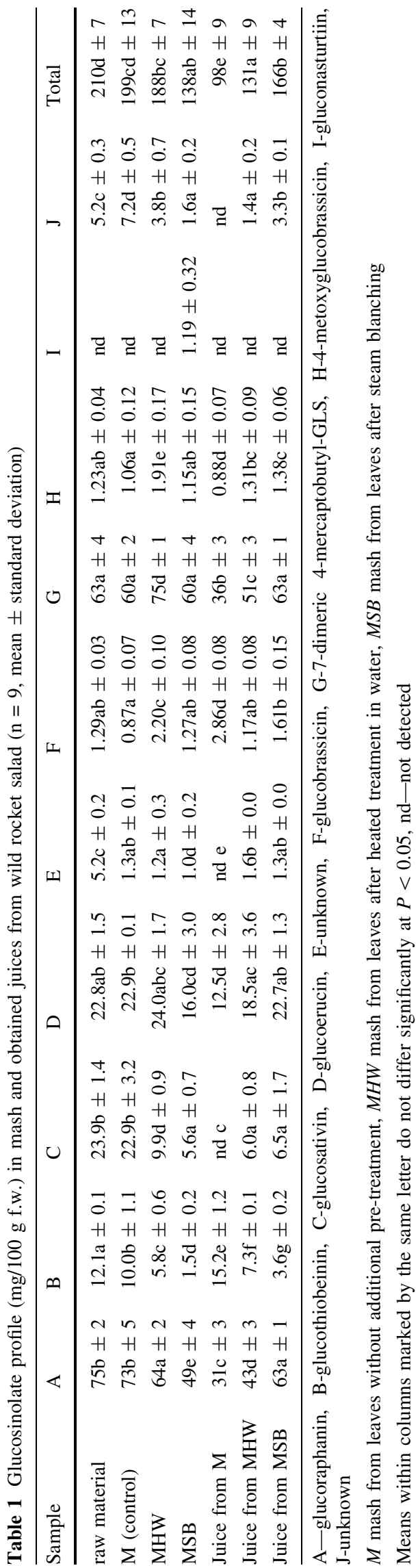


epiprogoitryn, which were not found in the samples tested in this study. Bell et al. (2015) reported glucosativin and DMB-GLS as dominant compounds, (approx. 90\% of total glucosinolate content). In study by Taranto et al. (2016), content of glucosativin and DMB-GLS was $51 \%$ of total GLS content. Considerable percentage differences for each glucosinolate type in the total content may result from the effect of growing conditions and climatic factors. For instance, Selma et al. (2010) reported the effect of soil amendments prepared from organic wastes (sewage sludge and urban solid waste) on a reduction of individual glucosinolate content in rocket leaves (Eruca sativa). Kim et al. (2002) found that glucosinolate content from the edible parts of Brassica rapa was strongly affected by $\mathrm{N}$ and S applications. Ciska et al. (2000) described the impact of climatic conditions (temperature and precipitation) on the content of GLS in vegetables.

Pretreatment of comminuted leaves with hot water and steaming resulted in a $10 \%$ and $34 \%$ reduction in contents of GLS respectively, in comparison to the raw material. Both pretreatment with hot water and steaming leaves contributed to a significant decrease $(P<0.05)$ in the contents of glucoraphanin, glucosativin, glucothiobeinin. However, in the case of steaming the reduction in the contents of these glucosinolates was significantly higher $(P<0.05)$. Concentration of glucobrassicin, dimeric 4-mercaptobutyl and 4-methoxyglucobrassicin increased significantly $(P<0.05)$ as a result of pretreatment with hot water. This may have been connected with the greater recovery factors of these compounds from tissue. Gliszczyńska-Świgło et al. (2006) reported a 1.1-fold and 1.4-1.6-fold increase of the content of aliphatic and indole glucosinolates in broccoli upon thermal pretreatment in comparison to fresh broccoli. A 35\% increase in total extractable glucosinolates after microwave treatment of red cabbage in comparison to the raw material was found by Oerlemans et al. (2006).

In the control (M) and comminuted leaves after steaming (MSB), glucobrassicin, dimeric 4-mercaptobutyl and 4-methoxyglucobrassicin contents were comparable to those in the raw material (Table 1). There are different studies that indicate an advantageous effect of steaming limiting losses of glucosinolates in cruciferous vegetables. Volden et al. (2008b) when investigating the effect of water blanching, boiling and steam blanching of red cabbage chunks; recorded $64 \%, 38 \%$ and $19 \%$ reduction of glucosinolate contents, respectively. Boiling, water blanching and steam blanching applied for various cauliflower varieties caused losses of GLS amounting to 55\%, $42 \%$ and $19 \%$, respectively (Volden et al. 2009). Francisco et al. (2010) stated that boiling of turnip greens and turnip tops contributed to glucosinolate losses amounting to $64 \%$, while after steam blanching the losses ranges from 9 to
$21 \%$. However, losses caused by water blanching to a considerable degree are reported as dependent on the amount of the solution and may range from 18 to $82 \%$ (Dekker et al. 2000; Sones et al. 1984). Normally in this study, tested samples were treated with a $10 \%$ of water (relatively smaller), thus higher retention of these amounts may have depended on the water amount. Moreover, the effect of thermal treatment on glucosinolate content in the raw material is dependent on the type of raw material.

Glucosinolate concentrations of the raw juice from steamed leaves, hot water treatment and no pretreatment were $79 \%, 62 \%$ and $47 \%$ of total content, respectively (calculated on the basis of values in Table 1). The greater contents of these compounds in raw juices obtained from thermally treated leaves may be connected both with the higher pressing efficiency and inactivation of myrosinase. There are not many studies describing the content of glucosinolates in juices. Hallmann et al. (2017) showed that glucosinolates were detectable in fresh cabbage but not in sauerkraut juice. These authors suggest, it was connected with glucosinolates decomposition during fermentation process and may be related to myrosinase activity.

In the juice produced from the leaves which were treated with hot water and steam, the concentrations of glucoraphanin, dimeric 4-mercaptobutyl, glucosativin, glucoerucin, 4-metoxyglucobrassicin were found higher in comparison to raw juice produced from untreated mash. In the case of glucothioibeinin and glucobrassicin the highest content, among the tested juices, was found in the raw juice produced from untreated leaves (Table 1).

\section{Content of phenolic compounds}

In rocket leaves, quercetin derivatives accounting for 55\% of total phenolic compound content and the rest composed of hydroxycinnamic acids (Table 2). Taranto et al. (2016) when analysing wild rocket salads from various accessions also found quercetin derivatives as a dominant among flavonoids. They recorded flavonoid contents at comparable levels of $42-73 \mathrm{mg} / 100 \mathrm{~g}$ f.w. (assuming dry weight at $8.5 \%$ based on our determinations). Available literature data indicate a higher share $(80-90 \%)$ of flavonoids in the total content of phenolic compounds (Heimler et al. 2007; Taranto et al. 2016). However, these differences may be connected with growing conditions. For instance, Selma et al. (2010) reported the effect of soil amendments prepared from organic wastes (sewage sludge and urban solid waste) on a reduction in the content of flavonols in rocket leaves (Eruca sativa).

In mash obtained from hot water pretreatment leaves and no pretreatment (control), the content of phenolic compounds was the same as in the raw material. In samples from steamed leaves, their contents were $33 \%$ lower. 
Table 2 Phenol compounds content (mg/100 g f.w.) in the mash and the juices from wild rocket leaves $(\mathrm{n}=9$, mean \pm standard deviation)

\begin{tabular}{lccc}
\hline Sample & Hydroxycinamic acids & Derivatives quercetin & Total of phenolic compounds content \\
\hline Raw material & $38.5 \mathrm{e} \pm 4.9 \mathrm{e}$ & $47.8 \mathrm{f} \pm 1.3$ & $86.3 \mathrm{~b} \pm 3.6$ \\
M (control) & $35.8 \mathrm{e} \pm 0.8 \mathrm{e}$ & $47.2 \mathrm{f} \pm 0.2$ & $83.0 \mathrm{~b} \pm 1.0$ \\
MHW & $31.1 \mathrm{c} \pm 0.7 \mathrm{c}$ & $52.0 \mathrm{~g} \pm 2.3 \mathrm{~g}$ & $83.1 \mathrm{~b} \pm 3.0$ \\
MSB & $19.7 \mathrm{~d} \pm 0.8$ & $38.0 \mathrm{~d} \pm 0.4$ & $57.7 \mathrm{~d} \pm 0.5$ \\
Juice from M & $12.3 \mathrm{a} \pm 0.1 \mathrm{a}$ & $21.3 \mathrm{a} \pm 0.7 \mathrm{a}$ & $33.6 \mathrm{a} \pm 0.8$ \\
Juice from MHW & $16.1 \mathrm{~b} \pm 1.9$ & $29.3 \mathrm{c} \pm 0.9 \mathrm{c}$ & $45.4 \mathrm{c} \pm 2.9$ \\
Juice from MSB & $13.2 \mathrm{ab} \pm 0.2 \mathrm{a}$ & $24 . \mathrm{b} 1 \pm 0.2$ & $37.3 \mathrm{a} \pm 0.2$ \\
\hline
\end{tabular}

$M$ mash from leaves without additional pre-treatment, $M H W$ mash from leaves after heated treatment in water, $M S B$ mash from leaves after steam blanching

Means within columns marked by the same letter do not differ significantly at $P<0.05$

Steaming reducing specific phenolic content, hydroxycinnamic acids by $49 \%$ and quercetin derivatives by $21 \%$ compare to the raw material. For quercetin derivatives the highest recovery rates were observed in samples obtained from leaves pretreated with hot water, even more phenolic compounds passed compared to the raw material (Table 2). Some authors suggested, that better recovery rates of phenolic compounds can be reached with the thermal treatment (Puupponen-Pimia et al. 2003). Most literature data indicate greater retention of phenolic compounds in Brassica vegetables as a result of steam blanching rather than water blanching (Zhang and Hamauzu 2004; Pellegrini et al. 2010). For example, Volden et al. (2008a) when investigating the effect of various thermal treatment methods for red cabbage found a $43 \%$ decrease in phenolic contents in water blanched samples, in which the water: raw material ratio was 1:10. In the case of steam blanching they reported increased contents of analysed compounds. In our study, the highest recovery rates of phenolic compounds were observed in mash from hot water pretreatment leaves. However, this thermal treatment was applied with a $10 \%$ water usage, which may have limited losses of the analysed compounds. The effect of this factor was indicated in a study by Zhang and Hamauzu (2004), who found as much as a $72 \%$ reduction in phenolic compounds in broccoli florets boiled for $5 \mathrm{~min}$ using a vegetable-water ratio of 1:20. Vegetable variety was considered as an important factor for this result. This was indicated by a study that Amin and Lee (2005) conducted with water blanching application, who recorded a decrease in phenolic contents for red cabbage, white cabbage, mustard cabbage and Chinese white cabbage, while the content of phenolics increased in Chinese cabbage at the application of identical water blanching conditions.

The highest content of phenolic compounds among the tested juices was recorded in raw juice produced from hot water treatment leaves $(53 \%$ of total of the phenolic compound content in raw material). In raw juices from untreated leaves (control) or steamed leaves the content of phenolic compounds was approx. $20 \%$ lower. Hallmann et al. (2017) recorded, that the flavonoid content in sauerkraut juice was $50 \%$ lower than in raw material. The level of hydroxycinnamic acids in wild rocket raw juices ranged from 12.3 to $16.1 \mathrm{mg} / 100 \mathrm{~g}$. In the case of quercetin derivatives the highest content was found in raw juices produced from leaves subjected to pretreatment with hot water, followed by those from steamed leaves and untreated leaves (control) (Table 2). A lower content of phenolic compounds in raw juices produced from untreated leaves (control) or steamed leaves may be the result of either a lack or incomplete inactivation of polyphenol oxidase. Wang et al. (2019) also reported that thermal processed kale juices exhibited higher total phenolics than the cold-pressed juice. These authors indicate that the thermal processing might have removed sugar moiety from flavonoid glycosides in kale to get free hydroxyl groups. Therefore, thermal-processed juices had higher phenolic compound content and radical scavenging activities compared to cold-pressed juices.

\section{Antioxidant capacity}

Antioxidant capacity recorded for the raw material and for the mash ranged from 6.7 to $10.4 \mu \mathrm{mol} / \mathrm{g}$ f.w. Steaming pretreatment caused to significant decrease in antioxidant capacity $(P<0.05)$. In raw juices the highest antioxidant capacity was found for samples obtained from mash from leaves subjected to pretreatment with hot water (Table 3). A strong correlation $(r=0.93)$ was observed between contents of phenolic compounds and antioxidant capacity. A significant correlation between antioxidant capacity and phenolic content for leaves of various Brassicaceae species (including salad rocket) $(\mathrm{r}=0.86)$ was also reported by Martínez-Sánchez et al. (2008). Heimler et al. (2007) also indicated such kind of correlation in other raw materials 
Table 3 Antioxidant capacity ( $\mu$ mol Trolox/1 g f.w.) in the mash and the juices from wild rocket leaves $(n=9$, mean \pm standard deviation)

\begin{tabular}{lr}
\hline Sample & \multicolumn{1}{l}{ ABTS } \\
\hline Raw material & $9.1 \mathrm{de} \pm 0.3$ \\
M & $10.4 \mathrm{e} \pm 0.7$ \\
MHW & $7.6 \mathrm{~cd} \pm 1.5$ \\
MSB & $6.7 \mathrm{bc} \pm 1.4$ \\
Juice from M & $3.3 \mathrm{a} \pm 0.1$ \\
Juice from MHW & $5.8 \mathrm{~b} \pm 0.0$ \\
Juice from MSB & $3.9 \mathrm{a} \pm 0.3$ \\
\hline
\end{tabular}

$M$ mash from leaves without additional pre-treatment, $M H W$ mash from leaves after heated treatment in water, $M S B$ mash from leaves after steam blanching

Means within columns marked by the same letter do not differ significantly at $P<0.05$

from Brassicaceae family (broccoli, cabbage) with the exception of cauliflower.

\section{Cytotoxic activity of wild rocket raw juice}

Wild rocket raw juice obtained from pretreatment with hot water leaves was evaluated for its cytotoxic activity to the cells originating from the gastrointestinal tract, including the small intestine (IEC-6 cell line), colon (Caco-2 cell line) and the liver (HepG2 cell line). As shown in Fig. 1, the impact of wild rocket raw juice on cell proliferation and viability is strictly dose-dependent. The raw juice at the lowest concentration $(0.03 \mathrm{mg} / \mathrm{ml})$ did not affect the cell culture growth $(P>0.05)$. The initial cytotoxic activity at which wild rocket raw juice reduced the metabolic activity of the IEC-6, Caco-2 and HepG2 cells by $10 \%\left(\mathrm{EC}_{10}\right)$, were calculated at $0.66 \pm 0.03 \mathrm{mg} / \mathrm{mL}, 0.04 \pm 0.01 \mathrm{mg} /$ $\mathrm{mL}$ and $0.46 \pm 0.02 \mathrm{mg} / \mathrm{mL}$, respectively (Table 4).

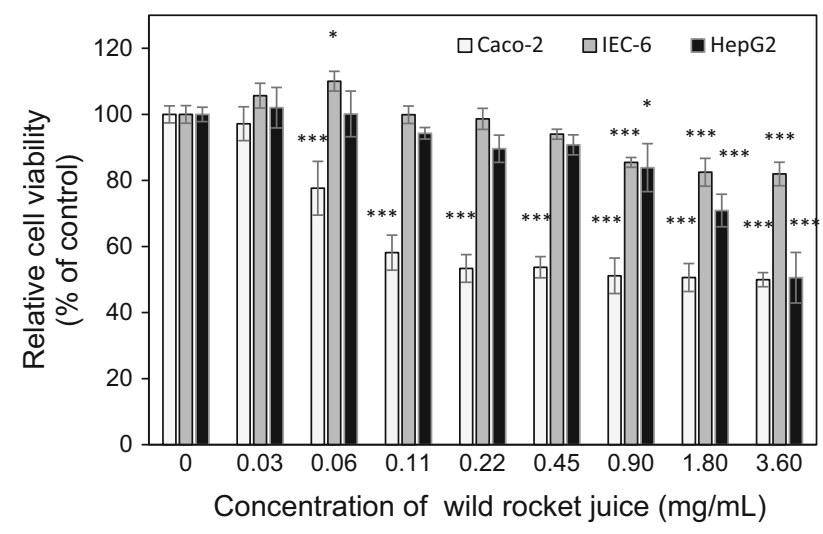

Fig. 1 The effect of wild rocket juice on the cell viability and metabolic activity measured using the MTT test. Statistically significant differences $* P<0.05, * * P<0.01, * * * P<0.001$ versus control group
Table 4 Cytotoxic doses of wild racket juice determined in IEC-6, Caco-2 and HepG2 cell cultures $(n=3$, mean \pm standard deviation)

\begin{tabular}{llll}
\hline Cytotoxic dose & IEC-6 cells & Caco-2 cells & HepG2 cells \\
\hline $\mathrm{EC}_{10}(\mathrm{mg} / \mathrm{mL})$ & $0.66 \pm 0.03$ & $0.04 \pm 0.01$ & $0.46 \pm 0.02$ \\
$\mathrm{EC}_{50}(\mathrm{mg} / \mathrm{mL})$ & $>3.60 / \mathrm{nd}$ & $1.87 \pm 0.08$ & $3.54 \pm 0.29$ \\
\hline
\end{tabular}

nd-non-detected in the concentration range from 0.03 to $3.60 \mathrm{mg} /$ $\mathrm{mL}$

Increasing the concentration of wild rocket raw juice in Caco-2 and HepG2 cell cultures caused a significant limitation of cell growth and decrease of cell viability (Fig. 1), which was reflected by the value of median effective concentration $\left(\mathrm{EC}_{50}\right)$. The wild rocket raw juice concentrations responsible for a $50 \%$ reduction in Caco-2 and HepG2 cell viability were estimated at $1.87 \pm 0.08 \mathrm{mg} /$ $\mathrm{mL}$ and $3.54 \pm 0.29 \mathrm{mg} / \mathrm{mL}$, respectively (Table 4). As shown in Fig. 1, the raw juice at the maximum concentration $(3.6 \mathrm{mg} / \mathrm{mL})$ reduced viability and metabolic activity of the IEC-6 cells by only $19.04 \pm 1.2 \%$. The results indicate that wild rocket raw juice exerts the strongest cytotoxic activity on colon Caco-2 cells $(F=54.0 ; P<0.0001)$, followed by HepG2 hepatocytes $(F=31.2 ; P<0.0001)$, and it shows the lowest cytotoxic activity in the culture of IEC-6 cells $(F=27.5$; $P<0.0001$ ) from the small intestinal epithelium (Fig. 1).

The cytotoxic activity of wild rocket on cancer cells was poorly investigated. Durazzo et al. (2013) describes such impact of polyphenolic wild rocket extract on Caco-2 cells for doses of $0.05 \mathrm{~mL} / \mathrm{mL}$ and $0.10 \mathrm{~mL} / \mathrm{mL}$. Cytotoxic activity of wild rocket raw juice may be related to the content of both phenolic compounds and glucosinolates. Therefore, further studies should be targeted to define the mechanisms of cytotoxic activity.

\section{Conclusion}

Conducted study show that hot water pretreatment of leaves and steaming caused a $10 \%$ and $34 \%$ reduction in contents of GLS in comparison to the raw material, respectively. In the produced raw juices the highest glucosinolate contents were recorded for samples from steamed leaves, followed by those from hot water treated leaves and untreated leaves (control). The greater contents of these compounds in raw juices obtained from thermally treated leaves may be connected both with the higher pressing efficiency and inactivation of myrosinase. In mash obtained from hot water pretreatment leaves and no pretreatment (control), the content of phenolic compounds was the same as in the raw material. In samples from steamed leaves, their contents were $33 \%$ lower. The highest content of phenolic compounds was found in raw juices produced 
from leaves pretreated with hot water. This may have resulted from differences in the distribution or binding of these compounds with the tissue of the tested raw material. Studies have also shown that wild racket juice in physiologically relevant doses does not induce cytotoxic effects on small intestinal epithelial cells. In contrast, treatment of colorectal cancer cells with low doses of wild rocket juice resulted in a significant reduction in cell proliferation and viability, which may suggest its anticancer potential. However, these preliminary in vitro studies should be continued in the future with a detailed analysis of antiproliferative mechanisms, including cell cycle progression and induction of apoptosis.

Acknowledgements This study was supported by a grant within the framework of project "Bioactive food" POIG 01.01.02-00-061/09.

\section{Compliance with ethical standards}

Conflict of interest The authors declare no conflict of interest.

Open Access This article is distributed under the terms of the Creative Commons Attribution 4.0 International License (http://crea tivecommons.org/licenses/by/4.0/), which permits unrestricted use, distribution, and reproduction in any medium, provided you give appropriate credit to the original author(s) and the source, provide a link to the Creative Commons license, and indicate if changes were made.

\section{References}

Amin I, Lee WY (2005) Effect of different blanching times on antioxidant properties in selected cruciferous vegetables. J Sci Food Agric 85(13):2314-2320. https://doi.org/10.1002/jsfa.2261

Bell L, Oruna-Concha MJ, Wagstaff C (2015) Identification and quantification of glucosinolate and flavonol compounds in rocket salad (Eruca sativa, Eruca vesicaria and Diplotaxis tenuifolia) by LC-MS: highlighting the potential for improving nutritional value of rocket crops. Food Chem 172:852-861. https://doi.org/ 10.1016/j.foodchem.2014.09.116

Bennett RN, Rosa EA, Mellon FA, Kroon PA (2006) Ontogenic profiling of glucosinolates, flavonoids, and other secondary metabolites in Eruca sativa (salad rocket), Diplotaxis erucoides (wall rocket), Diplotaxis tenuifolia (wild rocket), and Bunias orientalis. J Agric Food Chem 54(11):4005-4015. https://doi. org/10.1021/jf052756t

Chun JH, Kim S, Arasu MV, Al-Dhabi NA, Chung DY, Kim SJ (2017) Combined effect of nitrogen, phosphorus and potassium fertilizers on the contents of glucosinolates in rocket salad (Eruca sativa Mill.). Saudi J Biol Sci 24(2):436-443. https://doi. org/10.1016/j.sjbs.2015.08.012

Ciska E, Martyniak-Przybyszewska B, Kozlowska H (2000) Content of glucosinolates in cruciferous vegetables grown at the same site for two years under different climatic conditions. J Agric Food Chem 48(7):2862-2867. https://doi.org/10.1021/jf981373a

Dekker M, Verkerk R, Jongen WM (2000) Predictive modelling of health aspects in the food production chain: a case study on glucosinolates in cabbage. Trends Food Sci Tech 11(4):174-181. https://doi.org/10.1016/S0924-2244(00)00062-5
Durazzo A, Azzini E, Lazzè MC, Raguzzini A, Pizzala R, Maiani G (2013) Italian wild rocket [Diplotaxis tenuifolia (L.) DC.]: influence of agricultural practices on antioxidant molecules and on cytotoxicity and antiproliferative effects. Agriculture 3(2):285-298. https://doi.org/10.3390/agriculture3020285

Francisco M, Velasco P, Moreno DA, García-Viguera C, Cartea ME (2010) Cooking methods of Brassica rapa affect the preservation of glucosinolates, phenolics and vitamin C. Food Research International 43(5):1455-1463. https://doi.org/10.1016/j.foodres. 2010.04 .024

Giovannucci E, Rimm EB, Liu Y, Stampfer MJ, Willett WC (2003) A prospective study of cruciferous vegetables and prostate cancer. Cancer Epidemiol Prev Biomark 12(12):1403-1409

Gliszczyńska-Świgło A, Ciska E, Pawlak-Lemańska K, Chmielewski J, Borkowski T, Tyrakowska B (2006) Changes in the content of health-promoting compounds and antioxidant activity of broccoli after domestic processing. Food Addit Contam 23(11):1088-1098. https://doi.org/10.1080/02652030600887594

Hallmann E, Kazimierczak R, Marszałek K, Drela N, Kiernozek E, Toomik P, Matt D, Cuik A, Rembiałkowska E (2017) The nutritive value of organic and conventional white cabbage (Brassica oleracea 1. Var. Capitata) and anti-apoptotic activity in gastric adenocarcinoma cells of sauerkraut juice produced therof. J Agric Food Chem 65(37):8171-8183. https://doi.org/10. 1021/acs.jafc.7b01078

Heimler D, Isolani L, Vignolini P, Tombelli S, Romani A (2007) Polyphenol content and antioxidative activity in some species of freshly consumed salads. J Agric Food Chem 55(5):1724-1729. https://doi.org/10.1021/jf0628983

ISO:9167-1. (1992). Determination of glucosinolates content. Part 1: Method using high performance liquid chromatography

Katalinic V, Modun D, Music I, Boban M (2005) Gender differences in antioxidant capacity of rat tissues determined by $2,2^{\prime}$-azinobis (3-ethylbenzothiazoline 6-sulfonate; ABTS) and ferric reducing antioxidant power (FRAP) assays. Comp Biochem Physiol C Toxicol Pharmacol 140(1):47-52. https://doi.org/10.1016/j.cca. 2005.01.005

Kim SJ, Matsuo T, Watanabe M, Watanabe Y (2002) Effect of nitrogen and sulphur application on the glucosinolate content in vegetable turnip rape (Brassica rapa L.). Soil Sci Plant Nutr 48(1):43-49. https://doi.org/10.1080/00380768.2002. 10409169

London SJ, Smart J, Daly AK (2000) Lung cancer risk in relation to genetic polymorphisms of microsomal epoxide hydrolase among African-Americans and Caucasians in Los Angeles County. Lung Cancer 28(2):147-155. https://doi.org/10.1016/S01695002(99)00130-0

Mannozzi C, Fauster T, Haas K, Tylewicz U, Romani S, Dalla Rosa M, Jaeger H (2018) Role of thermal and electric field effects during the pre-treatment of fruit and vegetable mash by pulsed electric fields (PEF) and ohmic heating $(\mathrm{OH})$. Innov Food Sci Emerg 48:131-137. https://doi.org/10.1016/j.ifset.2018.06.004

Martínez-Sánchez A, Gil-Izquierdo A, Gil MI, Ferreres F (2008) A comparative study of flavonoid compounds, vitamin $\mathrm{C}$, and antioxidant properties of baby leaf Brassicaceae species. J Agric Food Chem 56(7):2330-2340. https://doi.org/10.1021/ jf072975+

Mosmann T (1983) Rapid colorimetric assay for cellular growth and survival: application to proliferation and cytotoxicity assays. J Immunol Methods 65(1-2):55-63. https://doi.org/10.1016/ 0022-1759(83)90303-4

Oerlemans K, Barrett DM, Suades CB, Verkerk R, Dekker M (2006) Thermal degradation of glucosinolates in red cabbage. Food Chem 95(1):19-29. https://doi.org/10.1016/j.foodchem.2004.12. 013 
Pasini F, Verardo V, Caboni MF, D’Antuono LF (2012) Determination of glucosinolates and phenolic compounds in rocket salad by HPLC-DAD-MS: Evaluation of Eruca sativa Mill. and Diplotaxis tenuifolia L. genetic resources. Food Chem 133(3):1025-1033. https://doi.org/10.1016/j.foodchem.2012.01. 021

Pellegrini N, Chiavaro E, Gardana C, Mazzeo T, Contino D, Gallo M, Rizo P, Fogliano V, Porrini M (2010) Effect of different cooking methods on color, phytochemical concentration, and antioxidant capacity of raw and frozen brassica vegetables. J Agric Food Chem 58(7):4310-4321. https://doi.org/10.1021/jf904306r

Puupponen-Pimiä R, Häkkinen ST, Aarni M, Suortti T, Lampi AM, Eurola M, Piironen V, Nuutila AM, Oksman-Caldentey KM (2003) Blanching and long-term freezing affect various bioactive compounds of vegetables in different ways. J Sci Food Agric 83(14):1389-1402. https://doi.org/10.1002/jsfa.1589

Radziejewska-Kubzdela E, Olejnik A (2016) Effects of pretreatment and modified atmosphere packaging on glucosinolate levels in coleslaw mix. LWT-Food Sci Technol 70:192-198. https://doi. org/10.1016/j.lwt.2016.02.052

Re R, Pellegrini N, Proteggente A, Pannala A, Yang M, Rice-Evans C (1999) Antioxidant activity applying an improved ABTS radical cation decolorization assay. Free Radical Bio Med 26(9):1231-1237. https://doi.org/10.1016/S0891-5849(98)003 15-3

Sapone A, Affatato A, Canistro D, Pozzetti L, Broccoli M, Barillari J, Iori R, Paolini M (2007) Cruciferous vegetables and lung cancer. Mutat Res-Rev Mutat 635(2):146-148

Selma MV, Martínez-Sánchez A, Allende A, Ros M, Hernández MT, Gil MI (2010) Impact of organic soil amendments on phytochemicals and microbial quality of rocket leaves (Eruca sativa). J Agric Food Chem 58(14):8331-8337. https://doi.org/10.1021/ jf1016187

Sones K, Heaney RK, Fenwick GR (1984) The glucosinolate content of UK vegetables-cabbage (Brassicae oleracea), swede (B. napus) and turnip (B. campestris). Food Addit Contam 1(3):289-296. https://doi.org/10.1080/02652038409385856

Taranto F, Francese G, Di Dato F, D'Alessandro A, Greco B, Onofaro Sanajà V, Pentangelo A, Mennella G, Tripodi P (2016) Leaf metabolic, genetic, and morphophysiological profiles of cultivated and wild rocket salad (Eruca and Diplotaxis spp.). J Agric Food Chem 64(29):5824-5836. https://doi.org/10.1021/acs.jafc. $6 \mathrm{~b} 01737$

Tsao R, Yang R (2003) Optimization of a new mobile phase to know the complex and real polyphenolic composition: towards a total phenolic index using high-performance liquid chromatography. J Chromatogr A 1018(1):29-40. https://doi.org/10.1016/j. chroma.2003.08.034

Turk MF, Baron A, Vorobiev E (2010) Effect of pulsed electric fields treatment and mash size on extraction and composition of apple juices. J Agric Food Chem 58(17):9611-9616. https://doi.org/10. $1021 /$ jf1016972

Vallejo F, Tomás-Barberán FA, García-Viguera C (2002) Potential bioactive compounds in health promotion from broccoli cultivars grown in Spain. J Sci Food Agric 82(11):1293-1297. https://doi. org/10.1002/jsfa.1183

van Poppel G, Verhoeven DT, Verhagen H, Goldbohm RA (1999) Brassica vegetables and cancer prevention. In: Zappia V, Della Ragione F, Barbarisi A, Russo GL, Iacovo RD (eds) Advances in nutrition and cancer 2. Springer, Boston, MA, pp 159-168

Volden J, Borge GIA, Bengtsson GB, Hansen M, Thygesen IE, Wicklund T (2008a) Effect of thermal treatment on glucosinolates and antioxidant-related parameters in red cabbage (Brassica oleracea L. ssp. capitata f. rubra). Food Chem 109(3):595-605. https://doi.org/10.1016/j.foodchem.2008.01. 010

Volden J, Wicklund T, Verkerk R, Dekker M (2008b) Kinetics of changes in glucosinolate concentrations during long-term cooking of white cabbage (Brassica oleracea L. ssp. capitata f. alba). J Agric Food Chem 56(6):2068-2073. https://doi.org/10.1021/ jf0731999

Volden J, Borge GIA, Hansen M, Wicklund T, Bengtsson GB (2009) Processing (blanching, boiling, steaming) effects on the content of glucosinolates and antioxidant-related parameters in cauliflower (Brassica oleracea L. ssp. botrytis). LWT-Food Sci and Technol 42(1):63-73. https://doi.org/10.1016/j.lwt.2008.05.018

Wang J, Jayaprakasha GK, Patil BS (2019) Chemometric characterization of 30 commercial thermal and cold processed juices using UPLC-QTOF-HR-MS fingerprints. LWT-Food Sci Technol. https://doi.org/10.1016/j.lwt.2019.108322

Zadernowski R, Oszmiański J (1994) Wybrane zagadnienia $z$ przetwórstwa owoców $i$ warzyw. Wydaw. ART

Zhang D, Hamauzu Y (2004) Phenolics, ascorbic acid, carotenoids and antioxidant activity of broccoli and their changes during conventional and microwave cooking. Food Chem 88(4):503-509. https://doi.org/10.1016/j.foodchem.2004.01.065

Publisher's Note Springer Nature remains neutral with regard to jurisdictional claims in published maps and institutional affiliations. 